\title{
Hubungan Gangguan Fungsi Kognitif Dengan Kejadian Depresi Pada Lansia Di Posyandu Lansia Ikur Koto Wilayah Kerja Puskesmas Ikur Koto Kota Padang
}

\author{
Zaliavani,I, ${ }^{1}$, Anissa, $\mathrm{M}^{2}$, Sjaff, $\mathrm{F}^{3}$ \\ ${ }^{1}$ Mahasiswa Fakultas Kedokteran Universitas Baiturrahmah, Padang, Indonesia \\ Email : : zaliavanii0@gmail.com \\ ${ }^{2}$ Bagian Psikiatri Fakultas Kedokteran Universitas Baiturrahmah, Padang, Indonesia \\ ${ }^{3}$ Bagian Ilmu Mikrobiologi Fakultas Kedokteran Universitas Baiturrahmah, Padang, Indonesia
}

\begin{abstract}
Abstrak
Latar Belakang: Pada usia lanjut stres lingkungan dan penurunan fungsi kognitif sering menyebabkan depresi. Depresi yang tidak tertangani dengan baik dapat menyebabkan peningkatan penggunaan fasilitas kesehatan, pengaruh negatif terhadap kualitas hidup lansia, bahkan dapat menyebabkan kematian. Tujuan: Penelitian ini bertujuan untuk mengetahui hubungan gangguan fungsi kognitif dengan kejadian depresi pada lansia di posyandu lansia Ikur Koto wilayah kerja Puskesmas Ikur Koto, Kota Padang. Metode: Jenis penelitian ini adalah penelitian analitik korelatif dengan pendekatan cross-sectional. Penelitian telah dilakukan di posyandu lansia Ikur Koto pada bulan Februari 2019. Sampel dalam penelitian ini lansia yang terdata posyandu lansia Ikur Koto wilayah kerja Puskesmas Ikur Koto, Kota Padang yang berjumlah 51 lansia. Analisa data adalah univariat disajikan dalam bentuk tabel distribusi frekuensi dan analisa bivariat dengan menggunakan uji spearman dengan menggunakan program SPSS. Hasil yang diperoleh dari 51 responden, usia terbanyak 60-74 tahun (elderly) yaitu $(70,6 \%)$, jenis kelamin terbanyak $(94,1 \%)$ adalah perempuan, pendidikan terbanyak $(56,9 \%)$ adalah SD, status perkawinan terbanyak $(52,9 \%)$ adalah kawin, status kesehatan terbanyak $(58,8 \%)$ tidak menderita penyakit kronis dan riwayat medikasi terbanyak (98\%) tidak mengkonsumsi obat, sebagian besar (71\%) tidak mengalami depresi, paling banyak (41,9\%) mengalami gangguan fungsi kognitif ringan dan terdapat hubungan yang signifikan antara gangguan fungsi kognitif dengan kejadian depresi pada lansia dengan nilai $\mathrm{p}=0,007<0,05$ dan $\mathrm{r}=-0,373$. Kesimpulan dari penelitian ini adalah terdapat hubungan yang signifikan antara gangguan fungsi kognitif dengan kejadian depresi pada lansia di posyandu lansia ikur koto wilayah kerja Puskesmas Ikur Koto, Kota Padang.
\end{abstract}

Katakunci — Depresi, gangguan fungsi kognitif, lansia

\section{Abstract}

Background: In the elderly, environmental stress and decreased cognitive function often cause depression. Depression that is not treated properly can cause an increase in the use of health facilities, a negative influence on the quality of life elderly, and can even cause death. Objective: of this research to know the relationship of cognitive function disorders with depression in the elderly at Posyandu Lansia Ikur Koto working area of the Puskesmas Ikur Koto, Padang. Method: This type of research is correlative analytic with cross-sectional approach. Research has been conducted at posyandu lansia Ikur Koto in February 2019. The samples in this research was elderly who were recorded at the posyandu lansia Ikur Koto there were 51 elderly. Data analysis

Health \& Medical Journal 


\section{Heme, Vol I No 1 \\ January 2019}

univariate presented in the form of a frequency distribution table and bivariate analysis using the spearman test using the SPSS program. Result of the 51 respondents, the majority of age was 60-74 years old (70,6\%), the highest sex were women (94,1\%), the highest education was elementary school (56,9\%) ), the most marital status was married (52,9\%), the highest health status $(58,8 \%)$ did not suffer chronic diseases and most medical history does not use drugs (98\%), most (72,5\%) did not experiencing depression, most (37,3\%) had mild cognitive function disorders and there were relationship between cognitive function disorders and depression in the elderly with a value $p=0,007<0,05$ and $r=-0,373$. Conclusion is there were significant relationship between cognitive function disorders and depression in the elderly at Posyandu Lansia Ikur Koto working area of the Puskesmas Ikur Koto, Padang.

Keywords - Depression, cognitive function disorders, elderly

Email : heme@unbrah.ac.id 


\section{Pendahuluan}

Pada tahun 2012 jumlah lanjut usia (lansia) diseluruh dunia kurang lebih 600 juta jiwa dengan umur rata-rata 60 tahun. Indonesia termasuk salah satu negara yang jumlah lansianya bertambah paling cepat dengan jumlah lansia pada tahun 2012 adalah 20 juta jiwa dan sekitar $7,59 \%$ dari jumlah penduduk Indonesia. $^{2}$ Pada tahun 2017 jumlah penduduk di Sumatera Barat tercatat 5,294,610jiwa dengan jumlah lansia 458,549 jiwa. ${ }^{3}$

Ketika seseorang memasuki tahapan lansia, maka ia mengalami perubahan fisik, kognitif dan psikososial.Perubahan fisik yang terjadi dapat dilihat dari tanda-tanda sebagai berikut: timbul keriput,rambut beruban, gigi mulai ompong, pendengaran dan penglihatan mulai berkurang. ${ }^{4}$ Selainmengalami kemunduran fisik juga mengalami kemunduran fungsi intelektual termasuk fungsi kognitif. Di fase ini seseorang yang masih bisa berfungsi normal mulai sulit mengingat kembalinformasi yang telah di pelajari, tidak jarang di temukan oleh orang setengah baya.Mudah lupa ini dapat berlanjut menjadi Gangguan Kognitif Ringan ( Mild Cognitive Imprairment- MCI) sampai ke demensia sebagai bentuk klinis yang paling berat. Hal tersebut tentunya juga akan berpengaruh pada aktivitas sehari-hari (Activities of Daily Living-ADL) sehingga dapat menurunkan kualitas hidup lansia yang berimplikasi pada kemandirian dalam melakukan aktivitas hidup sehari-hari. ${ }^{5}$

Kemunduran fungsi fisik, kognitif dan psikososial umumnya menjadi suatu stresor bagi lansia karena pada saat menjadi tua akan terjadi penurunan kemampuan beradaptasi terhadap perubahan.Kurangnya kemampuan dalam beradaptasi secara psikologis terhadap perubahan yang terjadi pada dirinya, mengakibatkan seringkali terjadi permasalahan psikososial pada lansia, salah satunya depresi. ${ }^{4}$
Depresi merupakan gangguan alam perasaan yang berat dan ditandai dengan gangguan fungsi fisik dan fungsi sosial yang hebat, lama dan menetap pada individu tersebut.Pada tahun 2008 prevalensi depresi pada lansia di dunia berkisar $8-15 \%$ dan hasil meta analisis dari laporan negara-negara di dunia mendapatkan prevalensi rata-rata depresi pada lansia adalah 13,5\% dengan perbandingan wanita-pria $14,1 \%: 8,6 \%$. Data prevalensi depresi pada lansia di Indonesia cukup tinggi yaitu sebanyak $76,3 \%$ dengan proporsi pasien geriatri yang mengalami depresi ringan $44,1 \%$, depresi sedang sebanyak $18 \%$, depresi berat sebanyak $10,8 \%$, dan depresi sangat berat sebanyak $3,2 \%{ }^{8}$

Manifestasi depresi pada lansia berbeda dengan depresi pada pasien yang lebih muda.Gejala-gejala depresi sering berbaur dengan keluhan somatik.Keluhan somatik cenderung lebih dominan dibandingkan dengan mood depresi. Penyakit fisik yang diderita lansia sering mengacaukan gambaran depresi, antara lain mudah lelah dan penurunan berat badan. Inilah yang menyebabkan depresi pada lansia sering tidak terdiagnosa maupun diterapi dengan baik. $^{11,}$

Depresi yang tidak tertangani dengan baik dapat menyebabkan peningkatan penggunaan fasilitas kesehatan, pengaruh negatif terhadap kualitas hidup lansia, bahkan dapat menyebabkan kematian. Depresi menimbulkan ketidakseimbangan hormonal yang dapat memperburuk penyakit kardiovaskular, metabolisme serotonin yang terganggu pada depresi akan menimbulkan efek Trombogenesis, perubahan suasana hati (mood) berhubungan dengan gangguan respons imunitas termasuk perubahan fungsi limfosit dan penurunan jumlah limfosit serta pada depresi berat terdapat penurunan aktivitas Sel Natural Killer.Pasien depresi menunjukkan kepatuhan yang buruk pada program pengobatan maupun rehabilitasi.Keadaan tersebut dapat menyebabkan program pengobatan pada 
lansia tidak sempurna sehingga memperburuk kondisi perjalanan penyakit lansia tersebut. ${ }^{13}$

Puskesmas Ikur Koto adalah salah satu Puskesmas yang terletak di kecamatan Koto Tangah.Wilayah kerja Puskesmas Ikur Koto terdiri dari 2 Kelurahan dan dari kelurahan tersebut terdapat 8 posyandu lansia.Posyandu lansia Ikur Koto merupakan posyandu lansia yang memiliki angka kunjungan tertinggi.Posyandu lansia ini dilaksanakan di Kelurahan KPIK dengan angka kunjungan terakhir sebanyak 56 orang lansia. Berdasarkan data Dinas Kesehatan Kota Padang persentase lansia yang mendapat pelayanan kesehatan tertinggi adalah Puskesmas Ikur Koto sebanyak 61,15\%. Adanya permasalahan tersebut maka peneliti tertarik untuk meneliti hubungan gangguan fungsi kognitif dengan kejadian depresi pada lansia di posyandu lansia Ikur Koto wilayah kerja Puskesmas Ikur Koto Kota Padang.

\section{Metode Penelitian}

Penelitian ini merupakan penelitian Analitik korelatif dengan menggunakan pendekatan cross sectional. Populasi penelitian ini adalah lansia yang terdata di posyandu lansia ikur koto. Subjek dalam penelitian ini diambil secara Consecutive Sampling. Data pada penelitian ini diambil menggunakan data primer yaitu wawancara berdasarkan kuesioner. untuk mengukur depresi digunakan kuesioner Geriatric Depression Scale (GDS) sedangkan untuk menyukur kognitif menggunakan kuesioner Montreal Cognitive Assessment Indonesia (MoCAInA). Analisa data yang dilakukan setelah pengelolahan data hasil penelitian adalah Analisa Univariat dan Analisa Bivariat. Data diproses dan diolah dengan bantuan program komputer yaitu SPSS V.24

\section{HASIL}

Penelitian dilakukan terhadap 19 orang pasien tersangka efusi pleura tuberkulosis (EPTB) yang mengirimkan sampel cairan pleura ke laboratorium RSUP Dr. M. Jamil Padang dari bulan Juli 2016 sampai Januari 2017.

\section{A. Karakteristik Lansia}

Karakteristik dasar subyek penelitian dapat dilihat pada Tabel 1.

TABEL 1. DISTRIBUSI FREKUENSI KARAKTERISTIK LANSIA DI POSYANDU LANSIA IKUR KOTO WILAYAH KERJA PUSKESMAS IKUR KOTO, KOTA PADANG

\begin{tabular}{|c|c|c|c|c|c|c|}
\hline \multirow[t]{2}{*}{ Karakteristik } & \multirow[t]{2}{*}{$f$} & \multirow[t]{2}{*}{$\%$} & \multicolumn{2}{|c|}{ Depresi } & \multicolumn{2}{|c|}{$\begin{array}{l}\text { Tidak } \\
\text { Depresi }\end{array}$} \\
\hline & & & $f$ & $\%$ & $f$ & $\%$ \\
\hline \multicolumn{7}{|l|}{ Usia : } \\
\hline 60-74 Tahun & 36 & 70,6 & 8 & 57,1 & 29 & 78,4 \\
\hline 75-90 Tahun & 12 & 23,5 & 6 & 42,9 & 8 & 21,6 \\
\hline$>90$ Tahun & 3 & 5,9 & & & & \\
\hline \multicolumn{7}{|l|}{ Jenis kelamin: } \\
\hline Laki-Laki & 3 & 5,9 & 1 & 7,1 & 3 & 8,1 \\
\hline Perempuan & 48 & 94,1 & $\begin{array}{l}1 \\
3\end{array}$ & 92,9 & 34 & 91,9 \\
\hline \multicolumn{7}{|l|}{ Pendidikan: } \\
\hline SD & 29 & 56,9 & 1 & 71,4 & 19 & 51,4 \\
\hline SMP & 13 & 25,5 & 0 & 21,4 & 10 & 27 \\
\hline SMA & 8 & 15,7 & 3 & 7,1 & 7 & 18,9 \\
\hline PT & 1 & 2,0 & $\begin{array}{l}1 \\
0\end{array}$ & 0 & 1 & 2,7 \\
\hline \multicolumn{7}{|l|}{ Status perkawinan: } \\
\hline Kawin & 27 & 52,9 & 3 & 21,4 & 24 & 64,9 \\
\hline Janda/ Duda & 23 & 45,1 & 1 & 78,6 & 13 & 35,1 \\
\hline Tidak kawin & 1 & 2,0 & $\begin{array}{l}1 \\
0\end{array}$ & 0 & 0 & 0 \\
\hline $\begin{array}{l}\text { Status Kesehatan: } \\
\text { Tidak menderita } \\
\text { penyakit }\end{array}$ & 30 & 58,8 & 4 & 28,6 & 25 & 67,6 \\
\hline $\begin{array}{l}\text { Menderita 1- } \\
2 \text { penyakit }\end{array}$ & 21 & 41,2 & $\begin{array}{l}1 \\
0\end{array}$ & 71,4 & 12 & 32,4 \\
\hline $\begin{array}{l}\text { Riwayat medikasi: } \\
\text { Tidak konsumsi } \\
\text { obat }\end{array}$ & 50 & 98,0 & $\begin{array}{l}1 \\
3\end{array}$ & 92,9 & 37 & 100 \\
\hline $\begin{array}{l}\text { Mengkonsumsi } \\
\text { obat }\end{array}$ & 1 & 2,0 & 1 & 7,1 & & \\
\hline
\end{tabular}

Berdasarkan tabel 1 diperoleh pada sampel paling banyak berusia 60-74 tahun, jenis kelamin terbanyak adalah perempuan, pendidikan terbanyak adalah SD, status perkawinan terbanyak adalah kawin, status kesehatan paling banyak adalah tidak 
menderita penyakit dan riwayat medikasi hampir semuanya tidak konsumsi obat.

Pada lansia yang mengalami depresi didapatkan paling banyak pada rentang usia 60-74 tahun, berjenis kelamin perempuan, dengan pendidikan SD, status perkawinan janda, status kesehatan menderita penyakit dan tidakmengosumsi obat.

\section{B. Distribusi Frekuensi Lansia Dengan Depresi}

TABEL 2. DISTRIBUSI FREKUENSI DEPRESI LANSIA DI POSYANDU LANSIA IKUR KOTO WILAYAH KERJA PUSKESMAS IKUR KOTO, KOTA PADANG

\begin{tabular}{lll}
\hline Depresi Lansia & $\boldsymbol{f}$ & $\mathbf{\%}$ \\
\hline Tidak depresi & 37 & 72,5 \\
Depresi & 14 & 27,5 \\
\hline Jumlah & 51 & 100 \\
\hline
\end{tabular}

Tabel 2. diperoleh hasil dari 51 lansia, sebagian besar $(72,5 \%)$ tidak mengalami depresi.

\section{Distribusi Frekuesi Lansia Dengan Gangguan Fungsi Kognitif}

TABEL 3. DISTRIBUSI FREKUENSI GANGGUAN FUNGSI KOGNITIF LANSIA DI POSYANDU LANSIA IKUR KOTO WILAYAH KERJA PUSKESMAS IKUR KOTO, KOTA PADANG

\begin{tabular}{lll}
\hline $\begin{array}{l}\text { Gangguan Fungsi } \\
\text { Kognitif }\end{array}$ & f & \% \\
\hline Ringan & 19 & 37,3 \\
Sedang & 17 & 33,3 \\
Berat & 15 & 29,4 \\
\hline Jumlah & 51 & 100 \\
\hline
\end{tabular}

Berdasarkan tabel 3 diperoleh hasil dari 51 lansia, paling banyak $(37,3 \%)$ mengalami gangguan fungsi kognitif ringan.

\section{Hubungan Gangguan Fungsi Kognitif Dengan Kejadian Depresi}

TABEL 4. HUbUNGaN gangGUAN FUNGSI KOGNITIF DENGAN KEJADIAN DEPRESI PADA LANSIA DIPOSYANDU LANSIA IKUR KOTO WILAYAH KERJA Puskesmas IKUR Koto, Kota PADANG

\begin{tabular}{ll}
\hline & Depresi \\
\hline Gangguan fungsi & $\mathrm{r}=-0,373$ \\
kognitif & $\mathrm{p}=0,007$ \\
& $\mathrm{n}=51$ \\
\hline
\end{tabular}

Berdasarkan tabel 4, hasil uji statistik (spearman) diperoleh nilai $\mathrm{p}=0,007(\mathrm{p}<0,05)$, maka dapat disimpulkan bahwa terdapat hubungan yang signifikan antara gangguan fungsi kognitif dengan kejadian depresi pada lansia di posyandu lansia Ikur Koto wilayah kerja Puskesmas Ikur Koto, Kota Padang. Keeratan hubungan antara kedua variabel tersebut menunjukan koefisien korelasi (r) = -0,373 menunjukkan korelasi variabel dalam kategori lemah dengan arah yang negatif, artinya semakin rendah skor MoCA maka akan semakin tinggi skor GDS.

\section{Pembahasan}

\section{A. Karakteristik Lansia}

Berdasarkan penelitian diperoleh hasil dari 51 lansia paling banyak dengan usia 60-74 tahun dan jenis kelamin terbanyak adalah. Hasil ini sejalan dengan penelitian sebelumnya yang dilakukan oleh Kamajaya diperoleh hasil 41,2\% lansia dengan usia 6074 tahun (elderly) dan dengan jenis kelamin terbanyak adalah perempuan (72\%).43 Hasil tersebut sesuai dengan pernyataan WHO dimana di seluruh dunia terjadi peningkatan populasi lansia usia 60 tahun keatas mulai tahun 2010.44 Berdasarkan data kemenkes RI tahun 2017 jumlah lansia permpuan di Indonesia lebih banyak daripada lansia lakilaki.14

Berdasarkan penelitian diperoleh hasil lansia yang mengalami depresi paling banyak dengan usia 60-74 dan jenis kelamin terbanyak adalah perempuan pada lansia di posyandu lansia Ikur Koto wilayah kerja Puskesmas Ikur Koto, Kota Padang. Sejalan dengan penelitian sebelumnya yang dilakukan oleh Wulansari diperoleh hasil $63,6 \%$ lansia dengan usia $>70$ tahun dengan jenis kelamin terbanyak adalah perempuan (57,6\%).47 Resiko terjadinya depresi dapat meningkat dua kali lipat saat usia semakin meningkat.24 Secara alamiah, depresi yang lebih sering ditemukan pada perempuan merupakan dampak dari perubahan biologis 
terutama hormonal misalnya early onset of menopause atau postmenopause. 15

Berdasarkan hasil penelitian pendidikan terakhir responden terbanyak adalah SD yaitu $(51,6 \%)$. Sejalan dengan penelitian Prabashwari diperoleh hasil $(84,4 \%)$ tingkat pendidikan rendah. Hal tersebut dikarenakan pada jaman dahulu sekolah bukan menjadi hal yang deperhatikan oleh masyarakat dan pemerintah. Pemenuhan sandang dan pangan sering didahulukan daripada pendidikan. Status perkawinan terbanyak adalah kawin yaitu (52,9\%). Penelitian Wulansari diperoleh hasil status perkawinan lansia paling banyak menikah yaitu $(45,6 \%)$ lansia. Hal ini disebabkan usia harapan hidup perempuan yang lebih tinggi dibandingkan dengan usia harapan hidup laki-laki, sehingga persentase lansia perempuan yang berstatus cerai mati lebih banyak dibandingkan dengan lansia laki-laki. Sebaliknya lansia laki-laki yang bercerai umumnya segera kawin lagi.15,16,17

Tingkat depresi seseorang dapat semakin tinggi ketika tingkat pendidikan rendah. Sesuai dengan hasil penelitian ini pendidikan lansia terbanyak adalah SD. Status perkawinan terbanyak adalah janda/duda yaitu (78,6\%). Tidak dapat membina hubungan pernikahan atau ditinggalkan pasangan karena meninggal dapat memicu terjadinya depresi.18

Status kesehatan terbanyak lansia adalah tidak menderita penyakit kronis. Lansia di Posyandu Lansia Ikur Koto hampir semuanya tidak menderita penyakit kronis, hanya ada beberapa orang yang menderita penyakit seperti hipertensi dan diabetes melitus. Berdasarkan data puskesmas tahun 2017 hanya 33,5\% lansia di Posyandu Lansia Ikur Koto yang terdata menderita penyakit kronis.18,19

Riwayat medikasi responden hampir semuanya tidak mengkonsumsi obat (98\%).
Berbeda dengan penelitian Dasopang sebagian besar $(78,96)$ lansia mengkonsumsi obat. Berdasarkan data puskesmas tahun 2017 tidak ada lansia di Posyandu Lansia Ikur Koto yang terdata melakukan pengobatan maupun di rujuk. Sebagian besar lansia di Posyandu Lansia Ikur Koto berobat secara mandiri. Kebanyakan lansia tidak percaya dengan obat dari dokter sehingga mereka lebih sering menggunakan obatobatan tradisional (obat kampung).18,19

Status kesehatan terbanyak $(64,3 \%)$ pada lansia yang depresi menderita 1-2 penyakit kronis. Faktor risiko yang berhubungan kuat dengan terjadinya depresi adalah penyakit kronis. Pada penelitian ini penyakit kronis terbanyak yang dialami lansia dengan depresi di posyandu lansia ikur koto adalah diabetes melitus dan hipertensi. Pengobatan merupakan salah satu tindakan medis untuk memulihkan kembali kondisi tubuh. Namun, beberapa obat yang diberikan dapat menimbulkan gejala depresi pada lansia. Sejalan dengan hasil penelitian ini didapatkan riwayat medikasi terbanyak $(92,9 \%)$ mengkonsumsi obat. Obat -obat yang paling banyak digunakan adalah obat antihipertensi.18,19,20

\section{B. Kejadian Depresi}

Berdasarkan penelitian diperoleh hasil bahwa sebagian besar $(72,5 \%)$ tidak mengalami depresi pada lansia di posyandu lansia Ikur Koto wilayah kerja Puskesmas Ikur Koto, Kota Padang. Hasil penelitian ini mendukung penelitian sebelumnya yang dilakukan oleh Wulansari diperoleh hasil $(54,6 \%)$ lansia tidak mengalami depresi dan juga penelitian yang dilakukan oleh Prabhaswari juga memperoleh hasil paling banyak lansia tidak mengalami depresi yaitu $(75,6 \%) \cdot 21,22$

Mayoritas lansia tidak mengalami depresi. Hal ini dapat disebabkan oleh tingginya dukungan sosial dari lingkungan dan tingginya aktivitas harian lansia. Lansia 
dengan interaksi atau dukungan sosial yang tinggi akan merasa lebih nyaman dan bahagia, sehingga dapat menjauhkannya dari risiko depresi.22,23

Hasil penelitian ini juga dipengaruhi oleh bias dari peneliti sendiri. Hal ini disebabkan oleh peneliti yang kurang tepat dalam menjelskan maksud dari pertanyaan berdasarkan kuesioner. Karena peneliti kurang tepat dalam melakukan wawancara sehingga didapatkan hasil terbanyak lansia yang tidak mengalami depresi.22,23,24

\section{Gangguan Fungsi Kognitif}

Berdasarkan penelitian diperoleh hasil paling banyak mengalami gangguan fungsi kognitif ringan pada lansia di posyandu lansia Ikur Koto wilayah kerja Puskesmas Ikur Koto, Kota Padang. Sejalan dengan penelitian yang dilakukan oleh Coresa diperoleh hasil paling banyak lansia dengan gangguan kognitif probable. Hasil ini sesuai dengan kepustakaan yang mengatakan bahwa meningkatnya usia mengakibatkan perubahaan anatomi, seperti menyusutnya otak dan perubahan neurostransmitter yang mengakibatkan terjadinya penurunan fungsi kognitif. Selain itu, trauma kepala secara langsung dapat mencederai struktur dan fungsi otak sehingga dapat mengakibatkan gangguan kognitif, kesadaran dan tingkah laku. Riwayat cedera kepala disertai berkurangnya kesadaran meningkatkan resiko alzheimer disease 10 kali lipat. Hal tersebut dapat terjadi karena rusaknya pembuluh darah otak dan peningkatan stres serta hilangnya neuron pada otak. 22,23,24

\section{Hubungan Gangguan Fungsi Kognitif dengan depresi lansia}

Berdasarkan uji statistic spearman diperoleh nilai $\mathrm{p}=0,007 \quad(\mathrm{p}<0,05)$, maka dapat disimpulkan bahwa terdapat hubungan yang signifikan antara gangguan fungsi kognitif dengan kejadian depresi pada lansia di posyandu lansia Ikur Koto wilayah kerja Puskesmas Ikur Koto, Kota Padang.
Keeratan hubungan antara kedua variabel tersebut menunjukan koefisien korelasi $(r)=$ $-0,373$ berarti tingkat korelasi variabel dalam kategori lemah dengan arah yang negatif, artinya semakin tinggi skor gangguan fungsi kognitif yang lansia alami maka akan semakin rendah skor depresi.

Hasil ini sejalan dengan penelitian Juniarta bahwa hubungan antara depresi dan gangguan fungsi kognitif menunjukkan hasil yang bermakna $(\mathrm{p}<0,05) .57$ Hasil ini konsisten dengan studi di Cina yang menunjukkan hubungan yang signifikan antara depresi dan gangguan fungsi kognitif.22,23,24

Gangguan fungsi kognitif dikatakan sebagai salah satu faktor risiko independen terjadinya depresi. Kemampuan proses pikir dan gangguan konsentrasi merupakan salah satu kriteria diagnosis depresi. Defisit dalam fungsi eksekutif, penghambatan respon, perencanaan, dan pemantauan kinerja, terkait dengan respon pengobatan jangka panjang yang buruk dan disabilitas fungsional yang lebih besar pada pasien dengan depresi. Gangguan fungsi kognitif paling sering dialami oleh individu usia lanjut dengan lateonset depression.

\section{Kesimpulan Dan SARan}

Terdapat hubungan yang signifikan antara gangguan fungsi kognitif dengan kejadian depresi pada lansia. Fungsi kognitif dapat dikatakan sebagai salah satu faktor risiko terjadinya depresi. Pasien gangguan kogniti harus mendapatkan tatalaksana yang adekuat sehingga dapat mencegah timbulnya depresi.

\section{Daftar Pustaka}

[1] Kementrian Kesehatan RI. Situasi dan Analisys Lanjut Usia. Diakses 31 Mar 2016. Available 2014. from: http://www.depkes.go.id/

[2] Dinas Kesehatan Provinsi Sumater Barat. Profil Kesehatan Provinsi Sumatera Barat Tahun 2017. Padang; 2017 
[3] Azizah L. Keperawatan Lanjut Usia. Ed 1. Yogyakarta: Graha Ilmu; 2011

[4] Fadhia, N. Hubungan fungsi kognitif dengan kemandirian dalam melakukan activities of daily living (adl) pada lansia di upt pslu pasuruan. skripsi. 2012.

[5] Evy. 2008. Waspadai Depresi pada Lansia. Kompas. Diunduh dari Diakses tanggal 20 Agustus

2013. http://tekno.kompas.com/read/2008/ 06/26/1912429/ waspadai.depresi.pada.lansia.

[6] Soejono, C.H., Probosuseno, dan Sari, N.K. Depresi pada Pasien Usia Lanjut. Dalam: Sudoyo, A.W., Setiyohadi, B., Alwi, I., Simadibrata, M., dan Setiati, S., ed. Buku Ajar Ilmu Penyakit Dalam. Jakarta: Pusat Penerbitan Ilmu Penyakit Dalam Fakultas Kedokteran Universitas Indonesia, 3810-3816; 2014

[7] Nugroho, Wahjudi. Komunikasi dalam Keperawatan Gerontik. Jakarta: EGC. 2009.

[8] Kamajaya, danu. Hubungan depresi dengan demensia pada pasien lanjut usia dengan hipertensi primer. 2014

[9] WHO. DEMENTIA : A Public Health Priority.UK: WHO. 2011.

[10] Kementrian Kesehatan RI. 2016. Situasi Lanjut Usia (Lansia) di Indonesia. Diakses 5 Mar 2019. Available from: http://www.depkes.go.id

[11] Wulansari, ika yuni.(2015). Hubungan antara gangguan kognitif dengan depresi pada lanjut usia demensia di posyandu lansia [skripsi]. Surakarta: fakultas ilmu kesehatan universitas muhammadiyah Surakarta

[12] Kartika S. 2012. Gambaran Tingkat Depresi Pada Lanjut Usia (Lansia) Di Panti Sosial Tresna Wredha Budi Mulia 01 Dan 03 Jakarta Timur. J Univ Indones; $1-74.40$

[13] Riyadi S dan TP. Asuhan Keperawatan Jiwa. Yogyakarta: Graha Ilmu. 2009.

[14] Prabhaswari L, Ariastuti NLP. 2015. Gambaran Kejadian Depresi Pada Lanjut Usia Di Wilayah Kerja Puskesmas Petang I Kabupaten Badung Bali Multidisciplinary j and med res. 2015;7(1):14

[15] Saputri MAW, Indrawati ES. Hubungan antara Dukungan Sosial dengan Depresi pada Lanjut Usia yang Tinggal di Panti Wreda Wening Wardoyo Jawa Tengah. J Psikol Undip. 2011;9(1):65-72.

[16] Dasopang, Eva S, Harahap Urip, Lindarto Dharma. Polifarmasi dan interaksi obat pasien usia lanjut rawat jalan dengan penyakit metabolik. JFKI. 2015; 4(4):235-241

[17] Duckworth.2009. depression and chronic illness; fact sheet. National alliance on mental illness. www.cc.nih.gov/ccc/patient.education.

[18] Suardana, I.W. Hubungan Faktor Sosiodemografi, Dukungan Sosial, dan Status
Kesehatan dengan Tingkat Depresi pada Agregat Lanjut Usia. Majalah Kedokteran Indonesia, 57(7):233-8. 2011.

[19] Coresa T, Ngestiningsih D. Gambaran Fungsi Kognitif Pada Lansia Di Unit Rehabilitasi Sosial Pucang Gading Semarang. J Kedokt Diponegoro. 2017; 6(1):1-6

[20] Soejono $\mathrm{CH}$. Pengkajian paripurna pada pasien geriatric. dalam: Setiati S, Alwi I, Sudoyo AW, Simadibrata KM, Setiyohadi B, Syam AF, pengarang. Buku ajar ilmu penyakit dalam. edisi 6. Jakarta: Internapublishing; 2014. h. 3705-13

[21] Nazreddin ZS, Philips NA, Bedirian V, Charbonneau $\mathrm{S}$ et al. The montreal cognitive assessment, MoCA: a brief screening tool for mild cognitive impairment. American Geriatrics Society, 2005.

[22] Juniarta PM, sryana IGPS. 2018. Hubungan antara depresi, gangguan fungsi kognitif, dan kualitas hidup penduduk usia lanjut di Desa Pedawa, Kabupaten Singaraja, Bali. JPD Udayana.2(1):19-22

[23] Giri M, Chen T, Yu W, et al. Prevalence and correlates of cognitive impairment and depression among elderly people in the world's fastest growing city, Chongqing, People's Republic of China. Clin Interv Aging. 2016: 12: 1091-1098

[24] Gotlib IH \& Joormann J: Cognition and Depression: Current Status and Future Directions. Annu Rev Clin Psychol. 2010; 6:285-312.

Email : heme@unbrah.ac.id 